\title{
Development of Weaving Module Based on Local Loading in SMKN 1 Mesjid Raya Aceh Besar
}

\author{
Erni $^{1}$, Vita Pujawanti Dhana ${ }^{2}$, Novita $^{3}$ \\ Department of Family Welfare Education, Universitas Negeri Medan, Indonesia ${ }^{1,2,3}$ \\ ernisyuman@gmail.com
}

\begin{abstract}
Weaving is one of the subjects in the Design and Textile Craft Products study program at SMK N 1, Mesjid Raya in Aceh Besar. Songket craft that studied by students untouched by Aceh's local's content. The learning's process only uses textbook as student guide. The result is, the class becoming monotonic and can't motivated student to learn independently. Therefore, need to develop the teaching materials that can support students independently in studying and can making the active study conditions. The research has a goal to produce valid, practically, and effective's locals content base's module. This type of research is the 4-D Models research development. The research has three stages that are define stage, design stage, and develop stage. Define stage done by analyzing the learning syllabus's loom, analyzed weaving's material and discussions with colleagues. In the design stage produced the local content-based modules. Develop stage consist of validations stage that is consultation with material's expert, media's and linguistic expert; practicalities of using practicalities questionnaires, observing the learning implementations, interview students and teachers; effectiveness of using motivation's questionnaire, and observing cognitive and psychomotor learning activity outcomes of students The result showed the locals content base's module for making craft textile with songkets weaving technique is valid in term of the content and construction. Local content base's module is practically because can used without major obstacle, and effective because can increase student's motivation, activation, cognitive study result and psychomotor at making craft textile with songkets weaving's technique.
\end{abstract}

Keywords: module, vocational, weaving

\section{Introduction}


Education is the most important investment for the nation of Indonesia, because it is a means to form human resources that are qualified, both in terms of physical, mental and operational. The quality of education one is determined by learning. The quality of education lately is often the main highlight in the world of education.

Where today's cultural heritage is often thought to have no relevance to the present especially in the future, and has made some cultural heritage then weathered aged, displaced, and neglected. Preservation of a culture is effective when delivered through education. Because education is the process of forming a quality human resource that is capable of the knowledge of science, skills and positive attitude

In PP number 19 Year 2005 Article 20, it is said that teachers are expected to develop learning materials, which is then emphasized through regulation of the Minister of National Education (Permendiknas) No.41 year 2007 about the standard process, which among others Govern the learning process planning that requires educators in the education unit to develop a Learning Plan (RPP).

One element in RPP is a learning resource. Therefore, teachers are expected to develop learning modules as one of the learning resources. Permendiknas No.16 year 2007 on the academic qualification and competency Standards Part B also mentions that teachers as professional educators are expected to have the ability to develop learning modules according to the existing mechanisms With regard to students ' social characteristics and environment.

Results of observations and interviews conducted with the teachers of subjects weaving in the design and product study Program Kriya Tekstil in SMK N 1 Masjid Raya Aceh Besar which is a vocational middle school of arts, crafts, and technology mentions, Problems that arise in the learning of weaving, especially in the material making crafts weaving with songket weaving techniques that the teacher does not teach songket weaving that is typical Aceh regional.

Another fact is in general the weaving learning has not used the module of learning completely. Generally, teachers only use the book of packages as a reference in the learning process. In addition, teachers also mention the unavailability of teaching materials that are designed in accordance with the material characteristics and conditions of students in the classroom and lead students to self-study.

Another thing that is also a problem is that it is based on the fact that at this time songket weaving Aceh has been very rare so that the more unknown it exists, and it is unfortunate that the number of traditional weavers in Aceh today Very little is even feared lost at all. This was delivered by the chairman of the UPTD Aceh Museum in the traditional weaving exhibition of Nusantara in Aceh Museum complex.

The statement was also strengthened by observations and other interviews obtained from the owner of the center of Weaving in Aceh Besar where craftsmen are now very few and almost lost. For the moment only, the process of weaving songket Aceh can only be done by middleaged mothers who only have the ability to roll yarn, to punish, weave, while to produce a piece of woven fabrics of songket Aceh.

There are several work processes to do, such as: inhabiting, designing motifs, weaving, making tassel shawls and decorating the edges of songket woven fabrics for men's head coverings. From the mentioned work process, designing motifs and decorating the edges of Songket weaving is a staple that demonstrates the feature of Songket weaving in Aceh.

While in the weaving of songket Aceh There are several work processes to be able to produce the Aceh songket weaving cloth that is kneared yarn, inhabit, designing motifs, 
weaving, making tassel shawl and decorate the edges of the songket woven cloth for the head cover Men. From the process of work mentioned, designing motifs and decorating the edges of songket woven Aceh is a staple that demonstrates the characteristic of the songket weaving of Aceh area.

Based on the problems expressed above, as the passage of songket weaving Aceh can no longer be inherited by the younger generation. Therefore, it is important to develop the material about songket weaving Aceh. Therefore, researchers take the initiative to develop materials on weaving subjects with materials making crafts weaving with songket weaving techniques in the form of modules for students of Class XI SMK N 1 Masjid Raya Aceh Besar that can facilitate teachers and students In the practice of weaving the songket weaving fabrics Aceh and also as a form of preservation of cultural and handicraft area of Aceh.

\section{Research Methods}

The research was conducted in SMK N 1 Masjid Raya Aceh Besar in design study and textile products. Development of local load-based learning module focuses on the learning of weaving for the material of weaving Kriya woven with songket weaving technique, and module trials are implemented only in the students of class XI SMK N 1Masjid Raya Aceh Besar which is the number of 20 Students.

The instruments in this study are instruments of validity. The instrument is used to determine whether a local payload-based module has been designed to be valid or not. In other words, all instruments that have been designed will be validated in advance to determine the level of validity of the instrument. The validation sheet on this research, namely:
a. Local load Module validation sheet,
b. RPP validation Sheet,
c. Validation sheet of teacher and student interviews,
d. Validation sheet of student activity observation,
e. Validation questionnaires Motivation Sheet
f. Validation sheet questionnaires practicality,
g. Effective questionnaires Validation Sheet

The instruments above is validated by 5 experts, namely: material experts, media experts, and linguists. The development procedure of this module uses 4-D models that are discovered by Thiagarajan. This Model consists of four stages, namely 1) definition, 2) design, 3) development, and 4) dissemination. In this research researchers only conducted 3 stages, namely the definition, design, and development of the fourth stage because of the long time, the number of SMK and samples are many and require more funds. More research plans can be described as follows: (a) phases of definition, including: syllabus analysis, material analysis and analysis of students (b) phases of designing, including: compiling modules and components of detailed drafting modules (c) Phase development, including: module validation phase, by requesting faculty and teacher degrees to: (1) View the feasibility of developed modules and the truthfulness of learning concepts that have been made, (2) Lecturers and teachers are required to provide a module review that has been Created based on the item on the validity questionnaire, and (3) after the assessment, the researcher revises the learning module according to the advice given by the validator and subsequently in the exam, (d) The practical stage, this practical test By providing questionnaires to students, and also conduct interviews with teachers 
and students, (e) The level of effectiveness, activities centered to evaluate whether local payload-based weaving modules can be used to achieve effective objectives in improving learning quality and student achievement.

\section{Data Analysis}

Data obtained from various instruments is divided into data validity, practicality, and effectiveness. Validity data is obtained from the validation sheet, practical data is obtained from a practical Questionnaire, interview guide, and observation sheet for the implementation of the learning. While data effectiveness is obtained from the poll sheet motivation and observation of student activities and learning outcomes (cognitive and psychomotor). Data is analyzed qualitatively and quantitatively. The results gained from observation of interviews and learning execution are analyzed qualitatively ideally. While the data obtained from the validation sheet, questioner practicality, activity observation sheets, will be analyzed quantitatively.

\section{Results and Discussion}

\section{Defining Phase Results}

a. Syllabus Analysis

The analysis of the syllabus was conducted against SK and KD in the syllabus obtained from the teacher weaving subjects, the explanation material weave incorporated in the SK, namely "make craft textiles with weaving techniques", and the basic competence is "make craft weaving with songket weaving techniques".

b. Material Analysis

The results of the analysis of SK and KD are used to formulate indicators for learning achievement in the material. To assemble the material in the module is also done by analyzing the reference book used by the teacher in the study and also from the research observations at the center of Weaving.

c. Student Analysis

Based on the results of interviews with teachers and students, locally developed load-based modules have been in line with the students ' conditions and characteristics. So that during the execution of the learning process is not found a meaningful obstacle and there are multi-directional interactions from students to students and from students to teachers.

\section{Design Phase Results.}

At this stage has been generated learning module of weaving based on local load according to the specifications of the product that has been designed, made, validated and also tested. The resulting module has a detailed array of module components.

\section{Results Stage Development}

a. Validity

The validation process can last more than once, according to the results obtained. Validation is terminated if it meets the predefined valid criteria. From a validator sheet obtained, then processed, analyzed, and revised according to the Comments and validator suggestions. The last average validation value that is obtained can be seen in the following table: 
Table 1. Score Eligibility Module

\begin{tabular}{llcl}
\hline No & \multicolumn{1}{c}{ Aspect Assessed } & $\begin{array}{c}\text { Validation } \\
\text { Score }\end{array}$ & Category \\
\hline a. & Goal & 3,4 & Very Valid \\
b. & Rational & 3,533 & Very Valid \\
c. & Contents of the module & 4 & Very Valid \\
d. & Characteristics of modules & 3,863 & Very Valid \\
e. & Conformity between components & 3,8 & Very Valid \\
f. & Pictures & 4 & Very Valid \\
g. & Language & 3,7 & Very Valid \\
h. & Physical form & 3,5 & Very Valid \\
i. & Flexibility & 4 & Very Valid \\
\hline \multicolumn{2}{c}{ Amount } & $\mathbf{3 3 , 7 9}$ & \\
\hline \multicolumn{2}{c}{ Average } & $\mathbf{3 , 7 5}$ & Very Valid \\
\hline
\end{tabular}

b. Practicality

The practical poll is distributed throughout the students in the test class, aiming to measure how practical the modules are developed for students ' learning. As for the distribution of the scores of practical poll as shown in the table below:

Table 2. Results of the analysis of the practicability of students

\begin{tabular}{clcc}
\hline No & \multicolumn{1}{c}{ Aspects } & $\begin{array}{c}\text { Practical } \\
\text { value }\end{array}$ & category \\
\hline 1 & Ease of Use & 3,55 & Very Practical \\
2 & Benefits & 3,4 & Very Practical \\
3 & Time-compliance & 3,51 & Very Practical \\
\hline & Average & $\mathbf{3 , 4 8}$ & Very Practical \\
\hline
\end{tabular}

\section{c. Effectiveness}

The effectiveness of the module is obtained by analyzing four indicators, namely: activity, motivation, and results of cognitive learning and psychomotor learning outcomes. To obtain data from all four indicators, a validated instrument of effectiveness is used. The following outlined analysis results in the effectiveness of modules.

\section{(1) Student's Activities}

The student activities observed include the following aspects; 1) Pay attention to and listen to the explanation of the teacher, 2) Read the learning module carefully, 3) Ask questions related to the material learned, 4) discuss with students and teachers, 5) Work out the question on the module, and 6) conclude the material. The results of observations on each aspect can be said that a lot of activity happens every meeting, 
average activity for every aspect of the category is very high i.e. in aspects of $1,2,5$; and the high category on aspects of 3, 4, and 6 , while the activity is generally in the high category with a percentage of $86 \%$. This gives an indication that if it is reviewed from student learning activities, the effective use of local payload-based modules is in the high category.

(2) Learning Motivation

Results of the analysis of the motivation questionnaire in the outline as shown in the table below:

Table 3. Analysis results of the students ' motivation learning

\begin{tabular}{clcc}
\hline No & Indicators & Motivation value & Category \\
\hline 1 & Desire to learn & 3,46 & Very high \\
2 & Hope to succeed & 3,46 & Very high \\
3 & Encouragement to learn & 3,75 & Very high \\
4 & Perseverance & 3,65 & Very high \\
\hline & Average & $\mathbf{3 , 5 8}$ & Very high \\
\hline
\end{tabular}

(3) Cognitive Learning Outcomes

The results of cognitive learning are derived from the test results given to students after learning using local payload-based modules. The question of the test is a multiple choice question. Each correct answer is given a score of 1, one 0 , and then the overall result is converted at intervals of $0-100$ so that it becomes a value for each student. The recapitulation of the learning outcomes which includes the average value and the classical learning submission can be seen in the following table:

Table 4. Recapitulation of student learning results in a classical

\begin{tabular}{ccccc}
\hline Average & $\begin{array}{c}\text { Completed } \\
\text { Students }\end{array}$ & $\begin{array}{c}\text { Students Not } \\
\text { Finished }\end{array}$ & KKM & Criteria \\
\hline 88,75 & 20 & - & 75 & Due Diligence \\
\hline
\end{tabular}

(4) Sychomotor learning outcomes

The results of learning in the realm of psychomotor obtained from the assessment/observation of students ' activities during the practice of making Kriya weaving with the techniques of songket weaving Aceh through the student psychomotor assessment instruments. Student assessments are performed individually in their respective groups. The results of learning data on the psychomotor aspects of students can be seen in the following:

Table 5. Student learning outcomes in psychomotor aspects 


\begin{tabular}{ccccc}
\hline No & Practice & $\begin{array}{c}\text { Aver } \\
\text { age }\end{array}$ & $\begin{array}{c}\text { Valu } \\
\text { e }\end{array}$ & $\begin{array}{c}\text { Criter } \\
\text { ia }\end{array}$ \\
\hline $\begin{array}{c}\text { 1. } \\
\text { Make a songket weaving Aceh with } \\
\text { a variety of pomegranate flowers }\end{array}$ & 90,5 & 80 & Good \\
\hline Average & $\mathbf{9 0 , 5}$ & $\mathbf{8 0}$ & Good \\
\hline
\end{tabular}

The development of local payload-based modules should have a baseline that is backed by local content learning. In this case, learning to weave on materials make crafts weaving with songket weaving techniques. As the problem has been disclosed, the development of modules that are deemed appropriate for such material is local payload based that can deliver students to learn the material related to the region.

Therefore, there is a need to follow up to optimize the utilization of local potentials as well as preservation efforts. This can be realized through education that is oriented towards local potentials by staying aimed to improve students ' abilities and achievements, because the education process is not only done by transferring the knowledge from the teacher to the students, but Students must be able to learn from the environment and daily life.

After the analysis of the syllabus and observations on the center of weaving to collect additional data needed in the design of a local payload-based weaving learning module, then the draft is consulted to get input about Need to do revision in order to guarantee the validity of the product.

Some of the improvements made are about the cover and language structure, shape or clarity of the image and the material writing systematics. From data analysis of the content validity and validity of the design that has been assessed by the validator indicates that the validity of the locally developed load-based module included in the criteria is very valid, this indicates that the developed learning module can measure what is supposed to be measured appropriately, and there is a connection between modules one and other modules/materials.

For practical testing, the results of a practical poll, observation and results of interviews on students and teachers regarding the use of learning modules during the learning process can generally be stated that the use of local payload-based modules Do not get any meaningful obstacles, in other words learn can run normally. Students happily learn by using modules, students also admitted easy in using the module. Criteria that obtained from the results of the questionnaire practical has a very practical criteria.

Test the effectiveness of modules based on the analysis of data observation of students ' activity during the learning activities with the module shows that learning by using the module has been encouraging to increase activity, motivation and Student learning outcomes.

Learning modules developed can help and facilitate teachers in explaining the learning materials and students in the study of weaving materials, especially materials making crafts weaving with songket weaving techniques Aceh.

\section{Conclusion and Suggestion} obtained:

Based on the data of development and test results that have been done, conclusions are

1) Has been produced learning module of local payload-based weaving on material making kriya weaving with songket weaving techniques Aceh. 
2) The locally generated payload-based weaving module is in the valid category, both from the didactic aspect, the construction aspect and the technical aspects.

3) The resulting module resides in a practical code both reviewed from ease of use, benefits gained and compliance with time.

4) The effectiveness of the module is in the effective category is indicated by the indicator of activity in the high category, the motivation to learn in a very high category of learning results are due category and the results of psychomotor learning are in good category.

Based on the conclusion that has been submitted, it is given some suggestions, namely:

1) The modules that are developed can be used by teachers and students in weaving lessons especially on the material making craft textiles with songket weaving techniques as a medium of learning and as an additional reference in weaving learning.

2) The modules that have been developed can also be used by the tourism office, the social service, and the Regional National Crafts Council in the implementation of songket weaving training in Aceh to list the crafts of Aceh.

3) For the management of time in learning with modules, it is recommended that the module be given a day before the study takes place so that students and teachers can better understand the material to be learned.

\section{References}

[1] Leigh, Barbara. Tangan- Tangan Terampi, Seni Kerajinan Aceh. Jakarta: Jhambatan. (1989)

[2] Kemendiknas. Petunjuk Teknis Penilaian Psikomotor. Jakarta. (2010)

[3] Sudirman. Interaksi dan Motivasi Belajar Mengajar. Jakarta: PT. Raja Grafindo Persada. (2010)

[4] Wacik, Jero. Tenun Ikat. Jakarta: Jhambatan. (2010)

[5] Wena, Made. Strategi Pembelajaran Inovatif Kontemporer. Jakarta: Bumi Aksara. (2010) 